\title{
Grammatical Errors in English for Office BLK Instructional Materials
}

\author{
Konstantinus Kapu*, Endah Dewi Muliandari, Deli Nirmala \\ Diponegoro University, Jl. Prof. Soedarto, SH, Semarang 50275, Indonesia
}

\section{A B S T R A C T}

English for Office is one of the programs that is conducted by Balai Latihan Kerja (or BLK for short) or Vocational and Education Training Center (VETC) in Kajen, Pekalongan. BLK has 30 students who prepare their English to work at offices. The English materials are supplied by BLK staff. This paper aims at finding out errors and inter-language phenomena which occur in the English for Office material used at BLK training. The data were collected by observing the English for Office material at BLK. The result shows that the English for Office materials at BLK have grammatical errors, inter-language issues, and sentence or item ambiguity. The grammatical errors consist of misused forms and ambiguous words. From the study, it can be recommended that there should be a proofreading and try out process in order that the materials have met quality control conditions.
A R T I C L E I N F O

Paper type:

Empirical Research Articel

Article history:

Received: 1 October 2018

Revised: 19 November 2018

Accepted: 19 November 2018

Keywords:

- English for Office Materials

- Grammatical Errors

- BLK

- Kajen Pekalongan

\section{Introduction}

Living in this digital and millennial era requires English as a tool for multicultural societies and cross cultural understanding in order to have a better communication skill among others. Relying on the significance of English, the learners need to have a good competence of English in speaking, listening, reading, or writing. Among these four skills, writing is indicated as the most difficult part in mastering English, because it needs not only grammatical and rhetorical devices but also conceptual and judgmental elements (Heaton, 1998). In spite of its difficulty, writing is an important part to deliver ideas and to underscore that someone is really literate. Being able to write in English is one of the goals of being English learners or scholars themselves. In order to achieve a well-structured idea, learners must be able to mix their knowledge (Harmer, 2004).

In our country; Indonesia, learning English as a foreign language is still a big problem because English is not an everyday language both in written and in spoken type. However, due to its importance as an international language, the learners encourage themselves to master the language. The spirit to be fluent in English is sometimes supported by having private English tutor, taking course outside the classroom, and learning English subject at university level as designed in the curriculum. However, for those who have no chance to go to university level or economically have a problem, they prefer to directly finding a job. Then in finding a job, it is undeniable that the requirement of mastering English is nowadays a need. Based on this need, our government provides such as BLK (Skill Learning Center) to deepen the learners' skills in listening, writing, speaking, and reading. Realizing this main goal, the English materials of BLK should encounter the need of the learners and the use of English materials should be designed well. For this reason, it is an important issue to observe the English materials used by BLK, because the English for Office material is a relatively new program. Due to its

\footnotetext{
* Corresponding Author.

E-mail addresses: konskapu@yahoo.com (K. Kapu), endahdewimli@gmail.com (E.D. Muliandari), deliundip@gmail.com (D. Nirmala).
} 
newness, this research is conducted to investigate the suitability of the handbook, particularly to discover whether or not it is appropriate enough to the participants' needs, so that the materials are well developed.

In a training process, instructional materials are needed in order to give clear guidance to the trainees. As guidance, they must be arranged well not only in terms of their content but also language used for instruction. The authors found some errors related to English grammar in the instructional materials used by BLK Kajen, Pekalongan. This preliminary observation requires the authors to study further to investigate the grammatical errors and other language problems which occur in the materials. According to James (1998), there are many types of errors and one of them is grammatical errors.

Writing about grammatical error analysis is not a new topic. Moreover, it is conducted in Indonesia where English is a foreign language. It is done in order to find a solution related to a method suitable for the learning process which can help learners improve their grammatical competence. Christina (2016), for example, conducted a grammatical error analysis on the students' English writing. Other writers like Krista \& Merili (2015), Kamlasi \& Nokas (2017), and Heryanti \& Sucipto (2017) conducted similar research. However, they are different in terms of the types of text analyzed and the respondents investigated. Christina (2016) studied the university students of UNSIQ Wonosobo, but Heryanti \& Sucipto (2017) studied Jambi University students' grammatical errors. A bit different study conducted by Krista \& Merili (2015) focusing on the grammatical mistakes and teaching strategies to encounter the problem.

The fifth research comes from Heryanti \& Sucipto (2017). It was analyzed by using format of error identification which revealed twelve errors. The data were collected through writing test. They were among other things verb tense, punctuation, capital letters, word choice, spelling, preposition, pronoun, pluralism, redundancy, word order, article and possessive case. There were 500 and 99 errors in students' papers, and the top level number of error occurred in verb tense category. There were three hundred and three errors on verb tense. It was about $50.58 \%$. Meanwhile, the lower level number of error occurred in article and possessive case category. The researcher concluded that the students made errors because of lack of grammatical knowledge. Their mother tongue; Bahasa Indonesia also still influences students' comprehension leading to making errors.

In developing instructional materials, the designers should consider not only their content but also context and ways of using instructions (Manurung, 2017). Making mistakes or errors is basically common in English language learning as a part of language learning. Corder (1981) viewed making errors as a process that someone undergoes in language learning whether in their mother tongue or their second language. There are five components of errors according to James (1998). The mistakes in English language learning are among other things misused forms like incorrect preposition, varied non-English acclamation, misuse of tenses form; wrong omissions of preposition and unnecessary words: articles, preposition; misplaced words like adverbs, adjective; and confused words like borrow or lend, lie or lay. Regarding written text, Brown (2004) shared four classifications of written text, namely imitative test, intensive test, responsive test, and extensive test. According to Brown (2004), there are several tests that can be applied in assessing intensive writing. Those tests are dictation and diction-computer focusing incorrect spelling, grammatical transformations task consisting of examining grammatical competence, picture cued-task as the connection between reading and writing, vocabulary assessment task about learning meaning of word, and task about how to order or reorder words into correct sentences. An argumentative writing is categorized as a kind of writing in which someone states his/her opinion to agree or disagree by mentioning the reason to support the agreement or disagreement. Argumentative writing enables students to think in their own way. Oshima \& Hogue (2006) mentioned five components of argumentative writing namely an explaining component of the current trend, a clear thesis statement, review of the disparate argument, refusal to disparate argument, and the writer's position.

Inter-language is considered a crucial topic in language learning due to its effect in making the language produced deviate rules in constructing acceptable forms of the language learnt. Since inter-language causes the learner's language to deviate from the norms that must be followed in arranging or using language. It seems that learners formulate a system by themselves. Corder (1981) states that inter-language is a kind of 'interference' of the learners' mother tongue. Inter-language happens individually in individual learners' language. According to Selinker (1972), there are five processes to second language learning i.e. language transfers involving rules and subsystem as results of the second language, transfer of training as result from specific features of the training process in teaching the second language, strategies of second language learning as result from approach to the material being learned, strategies of second language communication as result from specific ways of student's learning to communicate with native speakers of the target language.

Besides, there is also mistake related to system of language known as overgeneralization. Over generalization of target language of linguistic material as product of overgeneralization of rules and semantic features of target 
language. According to Jakobovits in Richards (1974), the use of previously available strategies in new situations is called overgeneralization; "In learning a second language.... few strategies will prove helpful in managing the facts about the second language, but others, probably due to superficial similarities, will be misleading and inapplicable".

There are a number of definition of writing skill as one of the competences in improving learners' English. Oshima \& Hogue (2006) stated that fixed writing skill is the result of written words that appear in the form of text, and the text itself can be read and understood in communication. A writer describes his/her ideas by writing a text so that the reader can find the meaning. Moreover, Oshima \& Hogue (2006) argued that writing is a kind of complex process. This process offers someone to express his/her ideas and thoughts. If ideas can be written down, at the same time those ideas are delivered to the readers. Writing has several styles, the classification of these styles can be seen in four categories (Hyland, 2002). Those classifications are that genre analysis aims to find reason of a problem, the discussion genre purposes to support an opinion or be opposite of something, the argument genre aims to persuade for a position, the report genre is to persuade for solution.

\section{Methods}

This study is descriptive in terms of its purpose that is describing errors and inter-language found in the instructional materials of Balai Latihan Kerja (or BLK for short). This research was conducted at BLK or Vocational and Education Training Center (VETC) in Kajen, Pekalongan regency. BLK is a training center for senior high school or tertiary level graduates who want to find a job as office staff. After having a certificate of English from Balai Latihan Kerja (BLK), they can work in different offices.

To collect the data, observing the instructional materials of English was conducted by identifying the grammatical errors, inter-language, and the words used. There were several steps done for collecting data. After identifying the errors, the researchers classified them in terms of types of errors, inter-language issues, and the causes of the errors. To analyze the data, referential and distributional methods were used. Finally, proposing correct forms was done. To analyze the data, English grammar theory was used beside dictionary and language in use theory.

\section{Results and Discussion}

The result of this research shows that the English for Office material has some grammatical errors, interlanguage issues, and ambiguous words. Inter-language phenomena are quite often found in the instructional materials of BLK. The following is the explanation of the errors and inter-language phenomena.

\subsection{Grammatical Errors}

Grammatical errors deal with misused forms like the use of verb forms, participial phrases as reduced clause, parallel constructions, prepositions, missing verbs, and word order. Besides, misspelling happens in the instructional material or textbook. The errors happening in the BLK textbook can be explained as follows. The examples of the misused forms can be presented in table 1.

Table 1. Misused Forms and their Correction

\begin{tabular}{|c|c|c|}
\hline No & Misused forms & Correction \\
\hline 1. & $\begin{array}{l}\text { We would appreciated having these items send before } 20^{\text {th }} \text { of } \\
\text { April } 2011 .\end{array}$ & $\begin{array}{l}\text { We would appreciate having these items sent } \underline{\text { by } 20 \text { th }} \\
\text { of April } 2011 .\end{array}$ \\
\hline 2. & $\begin{array}{l}\text { He saw her take out the typed sheet, put another one in, and then } \\
\text { quickly start on that page. }\end{array}$ & $\begin{array}{l}\text { He saw her taking out the typed sheet, putting another } \\
\text { one in, and then quickly starting on that page. }\end{array}$ \\
\hline 3. & You should come 10 minutes by at $10.30 \mathrm{am}$. & You should come 10 minutes by 10.30 . \\
\hline 4. & $\begin{array}{l}\text { The parking area is very large, the meal ready set up by } \\
\text { professional catering. }\end{array}$ & $\begin{array}{l}\text { The parking area is very large; the meal is ready to be } \\
\text { set up by professional catering. }\end{array}$ \\
\hline 5. & Which one of this symbol for sign "no neked flames & Which one of the symbols is naked flames? \\
\hline 6. & Which is sign for the airport? & Which sign leads to the airport? \\
\hline
\end{tabular}

Page 67 of the English for Office material presents an example of how to write a business letter. In the page, there is a misuse of verb form in writing the letter. The sentence is: we would appreciated having these items 
send before $20^{\text {th }}$ of April 2011. The words appreciated and send are incorrect. Here, the use of 'would' should be followed by infinite not by past form. For this reason, the sentence in this example of business letter should become we would appreciate having these items sent by 20th of April 2011. The use of auxiliary verb in English is always followed by infinitive. Then, the use of verb having these items send must be having these items sent. This form can be categorized as the third verb form or past participle indicating passive.

The next error is dealing with parallel construction. If there is a series of words, they should have in the same category or construction. The misused form can be found on page 12, when it talks about an example of reading a short story. In reading a past story, the tenses that are usually used are past forms. However, in this example there is a sentence 'he saw her take out the typed sheet, put another one in, and then quickly start on that page'. The verbs take, put, and start should be in parallel constructions of gerund forms. Therefore, the sentence should be 'he saw her taking out the typed sheet, putting another one in, and then quickly starting on that page.

The third error deals with preposition. If we look at page 35, there is an example of error. It stated ' $Y o u$ should come 10 minutes by at $10.30 \mathrm{am}$.' The use of wrong preposition in this sentence is a kind of incorrect omission. The preposition can be omitted because it is confusing. It should be 'You should come ten minutes before 10.30.' In the same page and example, there is also another misused tense and the wrong spelling of the word catering. The sentence is 'the parking area is very large, the meal ready set up by professional catering. This sentence should be 'the parking area is very large; the meal is ready to be set up by professional catering'.

Another incorrect omission can be found on page 30 as an example of business letter. The sentence is 'the fetures of our secretarial diploma course include'. In this sentence, the spelling of the word fetures should be features. In formulating a question on page 24 , it also shows two unordinary sentences namely which one of this symbol for sign "no neked flames and which is sign for the airport? In these two cases, the question has incorrect form. They must be which one of the symbols is naked flames? The other example is "Which sign leads to the airport?" These two incorrect sentences are the problems of question word in formulating a sentence.

\subsection{Confusing Words}

In the textbook, the errors found are confusing words resulting in ambiguity. The examples of confusing words can be seen in the table 2 .

Table 2. Confusing words

\begin{tabular}{|c|c|c|c|}
\hline No & Source Material & Analysis & Correction \\
\hline 1 & $\begin{array}{l}\text { We train }{ }^{\mathrm{a}} \text { the student for } \\
\text { administrative and executive }^{\mathrm{careers}} \underline{\text { and }}^{\mathrm{b}} \text { our employement } \\
\text { coreau } \underline{\text { help }}^{\mathrm{d}} \text { to post. }\end{array}$ & $\begin{array}{l}\text { a) The use of word "train" is not suitable enough to } \\
\text { the whole sentence. It is better to use the word } \\
\text { "prepare" } \\
\text { b) The sentence must be parallel because the use of } \\
\text { connector then and using comma before then. } \\
\text { c) The spelling of the word "employment", it must } \\
\text { be employment. } \\
\text { d) This sentence is a simple present form, so the } \\
\text { word "help" must be helps. }\end{array}$ & $\begin{array}{l}\text { We prepare the students for } \\
\text { administrative and executive } \\
\text { careers, then our employment } \\
\text { bureau helps to post. }\end{array}$ \\
\hline 2 & $\begin{array}{l}\text { In my country, there are many } \\
\text { freshness of the tropical } \\
\text { mountain air and village } \\
\text { atmosphere warmly welcome } \\
\text { you, so we are looking forward } \\
\text { to welcome you, when business } \\
\text { or vacation bring }{ }^{\text {b you to }} \\
\text { Puncak. }\end{array}$ & $\begin{array}{l}\text { a) Many can only be followed by plural nouns. } \\
\text { b) Then after the word bring, there must be 's' } \\
\text { because the sentence is simple present. }\end{array}$ & $\begin{array}{l}\text { In my country, there are many } \\
\text { tropical mountains which offer a } \\
\text { fresh air and village atmosphere } \\
\text { warmly welcoming you. } \\
\text { Therefore, we are looking } \\
\text { forward to welcoming you when } \\
\text { business or vacation brings you } \\
\text { to Puncak* }\end{array}$ \\
\hline
\end{tabular}

This sentence can be a possibility related to its ambiguity.

\subsection{Inter-language}

The inter-language issue that can be found in the textbook can be presented as follows. The inter-language happening in the textbook does not show different issues. 
'Mr. Iman wants Jenny to come to his office's room and he asks to her to photo copy Mr. Brown's proposal, and she responds: Yes, Mr. Iman. He said: please, photocopy this proposal. She responds: Yes sir! How many copies? And he responds: make two copies, she said: Yes, right away. And then Mr. Iman said: Oh Jenny. Return the original to Mr. Brown, and give me one copy and file the other. Jenny responds: Yes, Sir.'

The above conversation is an example how to ask a favor in the office on page 18. The language transfer of this conversation sounds unfamiliar in English use because of different patterns of the sentences and their subsystem as the result of the first language that is Bahasa Indonesia. The text structure seems to be a conversation in Indonesian way. In other words, the conversation is structured based on Indonesian way of thinking. Therefore, the target language seems weird. The main problem of this conversation is the pattern like 'He asks to her to photo copy.' This must be he asks her to copy. We must omit the word 'her'. Another problem is the capitalization of the English pronoun like he/she and verb said. It is grammatically wrong if it capitalizes in the middle of the sentence.

The last matter of inter-language can be found in the explanation of simple present. As an example, it is written 'I walk to walk and I don't walk to walk.' This sentence is grammatically correct but it does not have any sense. Probably it means 'I go to work on foot'

\section{Conclusions}

English for Office material at Balai Latihan Kerja (BLK) indicates grammatical errors, inter-language, and ambiguity. It absolutely needs to revise in order to provide a good instructional material. The authors strongly suggest Balai Latihan Kerja (BLK) or Vocational and Education Training Center (VETC) in Kajen, Pekalongan regency find proofreading agency before making the materials used for teaching and learning process, because a good material determines the quality of the institution and participants. Besides, it is also better to have assessment team in order to supply a good material for learners. In this case, there must be a team that checks or goes through the whole material and determines whether or not the material follows quality control.

To help trainees improve their English, the authors recommend them use Oxford intermediate English and English Grammar software. These two applications can help the trainees improve their English and use them at home. Besides, they provide various materials such as video, audio and grammar exercises with answer keys.

\section{References}

Brown, H. D. (2004). Language Assessment: Principles and Classroom Practices. New York: Pearson Education, Inc.

Christina. (2016). Grammatical error analysis of student's writing in the English department at faculty of Language and literature, UNSIQ Wonosobo Semarang. Diponegoro University, Faculty of Humanities. Semarang: Master Program in Linguistics.

Corder, S. P. (1981). Error Analysis and Interlanguage. Oxford: University Press.

Dahi, D. (2017, September 30). Pemerintah Asah Kompetensi Tenaga Kerja Lewat BLK. Diambil kembali dari Tribun News: http://www.tribunnews.com/kilas-kementerian/2017/09/30/pemerintah-asahkompetensi-tenaga-kerja-lewat-blk

Domasti, A. A. (2017, July 21). Melalui Balai Latihan Kerja, Kemnaker Harap Indonesia Tak Kalah Saing. Diambil kembali dari Kompass: https://nasional.kompas.com/read/2017/07/21/22421521/melalui-balailatihan-kerja-kemnaker-harap-indonesia-tak-kalah-saing

Harmer, J. (2004). How to Teach Writing. Essex. New Jersey: Pearson Education ESL.

Heaton, J. B. (1998). Longman Handbooks for Language Teachers: Writing English Language Test. New York: Longman, Inc.

Heryanti, R., \& Sucipto, H. (2017). The analysis of common grammatical errors in writing narrative essay of English study program students at Jambi University. Edukasi: Jurnal Pendidikan dan Pengajaran, 4 (2), 83-92.

Hyland, K. (2002). Second Language Writing. Cambridge University Press.

James, C. (1998). Errors in Language Learning and Use: Exploring Error Analysis. London: Routledge Taylor \& Francis Group. 
Kamlasi, I., \& Nokas, D. N. (2017). Grammatical Errors in Writing of The Second Class Students of SMA Kristen 1 Soe. Metathesis: journal of English language, literature, and teaching, 1 (1), 130-140.

Krista, U., \& Merili, L. (2015). Students'Grammar Mistakes and Effective Teaching Strategies. International Journal of Teaching and Education, III (1), 58-75.

Manurung, K. (2017). Designing Instructional Materials to Improve EFL Learning Achievement. International Journal of English Language, Literature and Humanities, 5 (II), 111-126.

Oshima, Oshima, A., \& Hogue, A. (2006). Introduction To Academic Writing. Pearson Education, Inc.

Richards, J. (1974). A Non-Contrastive Approach to Error Analysis, in Richards, Jack C (ed) Error Analysis Perspective on Second Language Acquisition. Essex: Longman.

Selinker, L. (1974). Interlanguage, in Richards, Jack C (ed) Error Analysis. Perspective on Second Language Acquisition. Essex: Longman. 